\title{
SARS-COV-2 infection during pregnancy, a risk factor for eclampsia or neurological manifestations of COVID-19? Case report
}

\author{
Alejandro Garcia Rodriguez ${ }^{1 \dagger}$, Sergio Marcos Contreras ${ }^{1 * \dagger}$ (D), Santiago Manuel Fernandez Manovel ${ }^{1}$, \\ Jose Miguel Marcos Vidal', Fernando Diez Buron ${ }^{1}$, Camino Fernandez Fernandez ${ }^{2}$ and \\ Maria del Carmen Riveira Gonzalez ${ }^{3}$
}

\begin{abstract}
Background: There are no published cases of tonic-clonic seizures and posterior bilateral blindness during pregnancy and Severe Acute Respiratory Syndrome (SARS) Coronavirus (COV) 2 (SARS-COV-2) infection. We do not just face new and unknown manifestations, but also how different patient groups are affected by SARS-COV-2 infection, such as pregnant women. Coronavirus Disease 2019 (COVID-19), preeclampsia, eclampsia and posterior reversible leukoencephalopathy share endothelium damage and similar pathophysiology.

Case presentation: A 35-year-old pregnant woman was admitted for tonic-clonic seizures and SARS-COV-2 infection. She had a normal pregnancy control and no other symptoms before tonic-clonic seizures development. After a Caesarean section (C-section) she developed high blood pressure, and we initiated antihypertensive treatment with labetalol, amlodipine and captopril. Few hours later she developed symptoms of cortical blindness that resolved in $72 \mathrm{~h}$ with normal brain computed tomography (CT) angiography.

Conclusion: The authors conclude that SARS COV-2 infection could promote brain endothelial damage and facilitate neurological complications during pregnancy.
\end{abstract}

Keywords: COVID-19, Case-report, Pregnancy, Preeclampsia, Neurological manifestations

\section{Background}

The vast majority of patients affected by SARS-COV-2 infection present flu-like symptoms $[1,2]$. However, as the pandemic evolves, a broader, diverse and unknown spectrum of symptoms can be observed. An increasing number of patients with neurological symptoms have been reported [3-6]. These manifestations can go from mild and common symptoms such as anosmia or ageusia, to severe ones and less common such as a cerebrovascular accident [3-6]. Symptoms of extrapulmonary disease could be explained by the damage of the endothelial tissue caused by the virus [7].

With this new virus, we do not just face new and unknown manifestations, but also how different patient groups are affected by SARS-COV-2 infection, such as pregnant women. That is the reason why we present a case report of a pregnant woman infected with SARSCOV-2 who showed seizures and sudden blindness.

\section{Case presentation}

We describe 35-year-old pregnant women with just hypothyroidism treated with thyroxin $88 \mu \mathrm{g}$ every $24 \mathrm{~h}$ as personal background and optimal blood pressure control

* Correspondence: s.marcos89@gmail.com

${ }^{+}$Alejandro Garcia Rodriguez and Sergio Marcos Contreras contributed equally to this work.

${ }^{1}$ Department of Anaesthesiology and Critical Care, University Complex Hospital of Leon, 24071 City Leon, Spain

Full list of author information is available at the end of the article

(C) The Author(s). 2020 Open Access This article is licensed under a Creative Commons Attribution 4.0 International License, which permits use, sharing, adaptation, distribution and reproduction in any medium or format, as long as you give appropriate credit to the original author(s) and the source, provide a link to the Creative Commons licence, and indicate if changes were made. The images or other third party material in this article are included in the article's Creative Commons licence, unless indicated otherwise in a credit line to the material. If material is not included in the article's Creative Commons licence and your intended use is not permitted by statutory regulation or exceeds the permitted use, you will need to obtain permission directly from the copyright holder. To view a copy of this licence, visit http://creativecommons.org/licenses/by/4.0/. The Creative Commons Public Domain Dedication waiver (http://creativecommons.org/publicdomain/zero/1.0/) applies to the data made available in this article, unless otherwise stated in a credit line to the data. 
during pregnancy, in her 40 weeks and 6 days of gestation. Pregnancy has been controlled by hospital protocols with no evidence of obstetric risk factors.

With no clinical manifestations the previous days, the patient was brought to our hospital due to generalized tonic-clonic seizures at home. The first suspicion was of eclampsia, and that was why an emergency C-section was performed. The same day the diagnosis of SARSCOV-2 infection was confirmed by immunoglobulin rapid test (I-RT) and nasopharyngeal Polymerase Chain Reaction (PCR) of the virus. The only abnormal results in the blood test at arrival to the hospital were Lactic Acid Dehydrogenase (LDH) of 336 UI/I and D-Dimer of $5781 \mathrm{ng} / \mathrm{ml}$. During her hospitalization, the blood creatinine values were within the normal range. The procedure was performed with general anaesthesia. Induction was made with propofol $200 \mathrm{mg}$ and rocuronium $100 \mathrm{mg}$. After birth, we started fentanyl $300 \mu \mathrm{g}$ and sevoflurane for maintenance of the anaesthesia without complications, completing postoperative care in the intensive care unit. After C-section, we initiated treatment with intravenous magnesium sulphate aiming levels between 4 to $6 \mathrm{mg} / \mathrm{dl}$, she developed high blood pressure with values of Systolic pressure higher than $160 \mathrm{mmHg}$ and diastolic pressure higher than $100 \mathrm{mmHg}$ and we started intravenous labetalol $60 \mathrm{mg}$ every hour for blood pressure control. After that, we introduced oral treatment with labetalol $100 \mathrm{mg}$ every $12 \mathrm{~h}$, captopril $25 \mathrm{mg}$ every $12 \mathrm{~h}$ and amlodipine $5 \mathrm{mg}$ every $12 \mathrm{~h}$. It allowed lowering the dose of intravenous labetalol progressively until suspension. Twenty-four hours after C-section, the risk index Soluble Fms-Like Tyrosine kinase-1/ Placental Growth Factor (sFlt-1/PlGF) was 51.4988.

Few hours after $\mathrm{C}$-section, the patient showed sudden blindness without other neurologic symptoms. Regarding to visual acuity: She could appreciate lights and shadows, being impossible with her degree of vision loss to achieve a low vision testing such as counting fingers or noticing moving objects with both eyes. Also, she had absence of the bilateral menace reflex (blink-to-threat reflex). The rest of the cranial nerves and neurological exam showed no pathological findings.

Due to these findings, a brain CT-scan and CTangiography were performed, existing no anomalies in these tests. We notified the case to the Neurology department who suspected posterior reversible leukoencephalopathy as a primary diagnosis, although there was no nuclear magnetic resonance confirmation. Because of this suspicion, we began treatment with subcutaneous enoxaparin $40 \mathrm{mg}$ every $24 \mathrm{~h}$.

The vision of the patient was recovered progressively during the first $48 \mathrm{~h}$ and the next day she was moved to a COVID-19 hospitalization area with antithrombotic and antihypertensive treatment. Currently, she has not any neurological symptoms and normal blood pressure without treatment.

\section{Discussion and conclusion}

The main manifestation of COVID-19 is influenza-like symptomatology but there are others such as anosmia or ageusia [1-6]. Not much has been said about different affectations in pregnant women or if this virus has any impact on the foetus. But it is important to have in mind that other coronaviruses such as SARS or Middle East Respiratory Syndrome (MERS) seems to increase complications such as preeclampsia [8].

In this case, we have a pregnant woman with positive COVID-19 I-RT and PCR that shows severe neurological symptoms. At first, the suspicion was eclampsia missing a diagnosis of preeclampsia during pregnancy, even when she had all the usual controls of pregnancy done and correct. The patient did not present any blood pressure alterations during those controls or in the ultrasound of the placenta. Also, she did not present any other suggestive clinic of preeclampsia. Twenty-four hours after C-section a risk index sFlt-1/PlGF was requested resulting high (51.4988) for diagnosis of preeclampsia in the next 4 weeks, but low for an imminent complication. The halflife of sFlt-1 is estimated in 1,4 days, while the half-life of PlGF is 3,7 [9], therefore the risk would not change. We also have the suspicion of neurological manifestations of COVID-19, where seizures are present in $0,7 \%$ of the cases [10], but she did not have any other clinical symptoms of COVID-19 such as headaches, ageusia or anosmia. Seizures are associated with previous history of cognitive impairment, older age, higher creatine Kinase levels and higher C-reactive protein [10].

SARS-COV-2 has been identified in brain endothelial cells [3]. Eclampsia, posterior reversible leukoencephalopathy and COVID-19 share a common pathophysiology affecting endothelial tissue [11, 12]. Therefore, we consider that SARS-COV-2 infection during pregnancy could increase the risk of suffering posterior reversible leukoencephalopathy or preeclampsia/eclampsia syndrome.

To conclude, we believe SARS-COV-2 infection could promote brain endothelial damage, triggering the cited neurological complications in our patient. To our knowledge, this is the first report of a patient with COVID-19 presenting preeclampsia associated with eclampsia versus posterior reversible leukoencephalopathy without alarm signs or symptoms. We consider further studies are needed to confirm that SARS-COV-2 infection is a risk factor to develop neurological complications of pregnant woman during pregnancy.

\section{Abbreviations}

COVID-19: Coronavirus Disease 2019; CT: Computed tomography; PCR: Polymerase chain reaction; LDH: Lactic Acid Dehydrogenase; 
SARS: Severe Acute Respiratory Syndrome; COV: Coronavirus; MERS: Middle East Respiratory Syndrome; I-RT: Immunoglobulin rapid test; Csection: Caesarean section; sFlt-1: Risk index Soluble Fms-Like Tyrosine kinase-1; PIGF: Placental Growth Factor

\section{Acknowledgements}

Not applicable.

\section{Methods}

The patient is included in other multicentre studies as patient with COVID19, same as the rest of patients with COVID-19 in our hospital. But there is no report or description of this particular case submitted.

\section{Authors' contributions}

AGR contributed to data collection, follow up and writing of the manuscript. SMC contributed to data collection, follow up and writing of the manuscript. CFF was the obstetrician of the patient, contributed to data collection and interpretation of the risk index sFIt-1/PIGF. SMFM was the anaesthesiologist of the patient during the C-Section, contributed to the initial diagnosis of eclampsia, interpretation of the first attention of the patient, as well as answering questions of the reviewers. JMMV and FDB were the anaesthesiologists at critical care department, contributed to data collection, writing of the manuscript and review of the hypothesis of endothelial damage. MCRG was the neurologist who contributed to the differential diagnosis, interpretation of the brain CT-scan and its concordance with the neurological exam. All authors have read and approved the final manuscript.

\section{Funding}

None.

\section{Availability of data and materials}

Data are available on request due to privacy or other restrictions. The data that support the findings of this study are available on request from the corresponding author SMC. The data are not publicly available due to them containing information that could compromise research participant privacy/ consent.

\section{Ethics approval and consent to participate}

Written consent was obtained from the patient to participate. According with The CARE Guidelines, case reports do not need ethics committee approval [13]. This manuscript fulfils the Declaration of Helsinki [14].

\section{Consent for publication}

Written consent was obtained from the patient for publication.

\section{Competing interests}

The authors do not have any conflict of interest and this publication does not have any funding.

\section{Author details}

${ }^{1}$ Department of Anaesthesiology and Critical Care, University Complex Hospital of Leon, 24071 City Leon, Spain. ${ }^{2}$ Department of Obstetrics and Gynaecology, University Complex Hospital of Leon, 24071 City Leon, Spain. ${ }^{3}$ Department of Neurology, University Complex Hospital of Leon, 24071 City Leon, Spain.

Received: 26 June 2020 Accepted: 21 September 2020

Published online: 06 October 2020

\section{References}

1. Zhou F, Yu T, Du R, Fan G, Liu Y, Liu Z, et al. Clinical course and risk factors for mortality of adult inpatients with COVID-19 in Wuhan, China: a retrospective cohort study. Lancet Lond Engl. 2020;395:1054-62. https://doi. org/10.1016/50140-6736(20)30566-3.

2. Wang D, Hu B, Hu C, Zhu F, Liu X, Zhang J, et al. Clinical characteristics of 138 hospitalized patients with 2019 novel coronavirus-infected pneumonia in Wuhan, China. JAMA. 2020. https://doi.org/10.1001/jama.2020.1585.

3. Mao L, Jin H, Wang M, Hu Y, Chen S, He Q, et al. Neurologic manifestations of hospitalized patients with coronavirus disease 2019 in Wuhan, China. JAMA Neurol. 2020. https://doi.org/10.1001/jamaneurol.2020.1127.
4. Butowt R, Bilinska K. SARS-CoV-2: olfaction, brain infection, and the urgent need for clinical samples allowing earlier virus detection. ACS Chem Neurosci. 2020;11:1200-3. https://doi.org/10.1021/acschemneuro.0c00172.

5. Giacomelli A, Pezzati L, Conti F, Bernacchia D, Siano M, Oreni L, et al. Selfreported Olfactory and Taste Disorders in Patients With Severe Acute Respiratory Coronavirus 2 Infection: A Cross-sectional Study. Clin Infect Dis. 2020. https://doi.org/10.1093/cid/ciaa330.

6. Eliezer M, Hautefort C, Hamel A-L, Verillaud B, Herman P, Houdart E, et al. Sudden and complete olfactory loss function as a possible symptom of COVID-19. JAMA Otolaryngol Neck Surg. 2020. https://doi.org/10.1001/ jamaoto.2020.0832.

7. Varga Z, Flammer AJ, Steiger P, Haberecker M, Andermatt R, Zinkernagel AS, et al. Endothelial cell infection and endotheliitis in COVID-19. Lancet. 2020; 395:1417-8. https://doi.org/10.1016/S0140-6736(20)30937-5.

8. Mullins E, Evans D, Viner RM, O'Brien P, Morris E. Coronavirus in pregnancy and delivery: rapid review. Ultrasound Obstet Gynecol Off J Int Soc Ultrasound Obstet Gynecol. 2020;55:586-92. https://doi.org/10.1002/uog. 22014.

9. Saleh $\mathrm{L}$, van den Meiracker AH, Geensen R, Kaya A, Roeters van Lennep JE, Duvekot JJ, et al. Soluble fms-like tyrosine kinase-1 and placental growth factor kinetics during and after pregnancy in women with suspected or confirmed pre-eclampsia. Ultrasound Obstet Gynecol. 2018;51:751-7. https:// doi.org/10.1002/uog.17547.

10. Romero-Sánchez CM, Díaz-Maroto I, Fernández-Díaz E, Sánchez-Larsen Á, Layos-Romero A, García-García J, et al. Neurologic manifestations in hospitalized patients with COVID-19: the ALBACOVID registry. Neurology. 2020. https://doi.org/10.1212/WNL.0000000000009937.

11. Mayama M, Uno K, Tano S, Yoshihara M, Ukai M, Kishigami Y, et al. Incidence of posterior reversible encephalopathy syndrome in eclamptic and patients with preeclampsia with neurologic symptoms. Am J Obstet Gynecol. 2016;215:239.e1-5. https://doi.org/10.1016/j.ajog.2016.02.039.

12. Brewer J, Owens MY, Wallace K, Reeves AA, Morris R, Khan M, et al. Posterior reversible encephalopathy syndrome in 46 of 47 patients with eclampsia. Am J Obstet Gynecol. 2013;208:468.e1-6. https://doi.org/10.1016/j.ajog.2013. 02.015 .

13. Gagnier JJ, Kienle G, Altman DG, Moher D, Sox H, Riley D, et al. The CARE guidelines: consensus-based clinical case reporting guideline development. Glob Adv Health Med. 2013;2:38-43. https://doi.org/10.7453/gahmj.2013.008.

14. General Assembly of the World Medical Association. World medical association declaration of Helsinki: ethical principles for medical research involving human subjects. J Am Coll Dent. 2014;81:14-8.

\section{Publisher's Note}

Springer Nature remains neutral with regard to jurisdictional claims in published maps and institutional affiliations.

\section{Ready to submit your research? Choose BMC and benefit from:}

- fast, convenient online submission

- thorough peer review by experienced researchers in your field

- rapid publication on acceptance

- support for research data, including large and complex data types

- gold Open Access which fosters wider collaboration and increased citations

- maximum visibility for your research: over $100 \mathrm{M}$ website views per year

At BMC, research is always in progress.

Learn more biomedcentral.com/submissions 